ISSN 0103-9954

\title{
ANNUAL VARIATION IN CANOPY OPENNESS, AIR TEMPERATURE AND HUMIDITY IN THE UNDERSTORY OF THREE FORESTED SITES IN SOUTHERN BAHIA STATE, BRAZIL
}

\author{
VARIAÇÃO ANUAL NA ABERTURA DO DOSSEL, TEMPERATURA E UMIDADE DO AR NO \\ SUB-BOSQUE DE TRÊS AMBIENTES FLORESTAIS NO SUL DA BAHIA, BRASIL
}

Marayana Prado Pinheiro ${ }^{1}$ Josafá Amaral de Oliveira Filho ${ }^{2}$ Solange França ${ }^{3}$ André Márcio Amorim ${ }^{4}$ Marcelo Schramm Mielke

\begin{abstract}
Aiming at contributing to the knowledge of physical factors affecting community structure in Atlantic Forest remnants of southern Bahia state, Brazil, we analyzed the annual variation in the understory microclimate of a hillside forest fragment in the 'Reserva Particular do Patrimônio Natural Serra do Teimoso' (RST) and a rustic cacao agroforestry system (Cabruca), located nearby the RST. Canopy openness $(C O)$, air temperature $(T a)$, air relative humidity $(R H)$ and vapor pressure deficit $(V P D)$ data were collected between April, 2005 and April, 2006 at the base $\left(\mathrm{RST}_{\mathrm{B}}, 340 \mathrm{~m}\right)$ and the top $\left(\mathrm{RST}_{\mathrm{T}}, 640 \mathrm{~m}\right)$ of the RST and at the Cabruca (CB, $250 \mathrm{~m})$. Data of rainfall, $T a, R H$ and $V P D$ were also collected in an open area (OA, $270 \mathrm{~m})$. The highest rainfalls $(>100 \mathrm{~mm})$ occurred in November, 2005 and April, 2006, whereas October, 2005 was the driest month $(<20 \mathrm{~mm}$ ). CO ranged between $2.5 \%$ in the CB (April, 2006) and $7.7 \%$ in the RST (October, 2005). Low rainfall in October, 2005 affected $V P D_{\max }$ in all sites. Those effects were more pronounced in $\mathrm{OA}$, followed by $\mathrm{CB}, \mathrm{RST}_{\mathrm{B}}$ and $\mathrm{RST}_{\mathrm{T}}$. During the period of measurements, the values of $\mathrm{Ta}$, $R H$ and $V P D$ in $\mathrm{CB}$ were closer to the values measured in $\mathrm{OA}$ than to the values measured inside the forest.
\end{abstract}

Keywords: Atlantic Forest; microclimate; rainfall; vapor pressure deficit.

\section{RESUMO}

Visando contribuir para o conhecimento dos fatores físicos que afetam a estrutura da comunidade vegetal em remanescentes de mata atlântica do sul da Bahia foi analisada a variação anual do microclima do subbosque num fragmento de floresta de encosta na Reserva Particular do Patrimônio Natural Serra do Teimoso (RST) e num sistema agroflorestal rústico utilizado para o cultivo do cacau (Cabruca), localizado nas proximidades da RST. Dados da abertura do dossel (CO), da temperatura do ar (Ta), da umidade relativa do ar $(R H)$ e do déficit de pressão de vapor (VPD) foram coletados entre abril de 2005 e abril de 2006 na base $\left(\mathrm{RST}_{\mathrm{B}}, 340 \mathrm{~m}\right)$ e no topo $\left(\mathrm{RST}_{\mathrm{T}}, 640 \mathrm{~m}\right)$ da RST e na Cabruca $(\mathrm{CB}, 250 \mathrm{~m})$. Dados de precipitação pluvial, $T a, R H$ e $V P D$ foram também coletados numa área aberta $(\mathrm{OA}, 270 \mathrm{~m})$. As maiores precipitações $(>100$ $\mathrm{mm}$ ) ocorreram em Novembro de 2005 e Abril de 2006, enquanto outubro de 2005 foi o mês mais seco (< $20 \mathrm{~mm}$ ). $C O$ variou entre $2,5 \%$ na CB (Abril, 2006) e 7,7 \% na RST (Outubro, 2005). Os baixos valores de pluviosidade registrados em Outubro de 2005 afetaram $V P D_{\max }$ em todos os ambientes. Estes efeitos foram mais pronunciados em OA, seguido de $\mathrm{CB}, \mathrm{RST}_{\mathrm{B}}$ e $\mathrm{RST}_{\mathrm{T}}$. Os valores de $T a, R H$ e $V P D$ em CB foram mais próximos aos valores observados em $\mathrm{OA}$ do que aos valores observados no interior da floresta.

Palavras-chave: déficit de pressão de vapor; Floresta Atlântica; microclima; precipitação pluvial.

1. Bióloga, Msc., Universidade Estadual de Santa Cruz, Campus Soane Nazaré de Andrade, km 16 Rodovia IlhéusItabuna, CEP 45662-900, Ilhéus (BA).

2. Biólogo, Msc., Universidade Estadual de Santa Cruz, Campus Soane Nazaré de Andrade, km 16 Rodovia IlhéusItabuna, CEP 45662-900, Ilhéus (BA).

3. Engenheira Agrônoma, Dra., Professora Titular do Departamento de Ciências Agrárias e Ambientais, Universidade Estadual de Santa Cruz, Campus Soane Nazaré de Andrade, km 16 Rodovia Ilhéus-Itabuna, CEP 45662-900, Ilhéus (BA).

4. Biólogo, Dr., Professor Titular do Departamento de Ciências Biológicas, Universidade Estadual de Santa Cruz, Campus Soane Nazaré de Andrade, km 16 Rodovia Ilhéus-Itabuna, CEP 45662-900, Ilhéus (BA).

5. Engenheiro Agrônomo, Dr., Professor Pleno do Departamento de Ciências Biológicas, Universidade Estadual de Santa Cruz, Campus Soane Nazaré de Andrade, km 16 Rodovia Ilhéus-Itabuna, CEP 45662-900, Ilhéus (BA). msmielke@uesc.br

Recebido para publicação em 6/07/2010 e aceito em 27/10/2011 


\section{INTRODUCTION}

The Brazilian Atlantic Forest is one of the most endangered forest biomes in the world (MYERS et al. 2000). Floristic inventories have shown that the southern Bahia holds a higher level of plant endemism in comparison with other regions of the Atlantic Forest (THOMAS et al., 1998) and one of the highest tree species diversity in the world (MARTINI et al. 2007; THOMAS et al., 2008). According to Mori and Silva (1978) and Thomas and Barbosa (2008), following a rainfall gradient from littoral to the interior, the vegetation of the southern Bahia region can be divided into four main vegetation types, i.e. wet forests, mesophytic forests, liana forest and 'caatinga'. The socioeconomic history of the region is linked to the cultivation of cacao trees (Theobroma cacao L.) in a rustic agroforestry system called 'Cabruca'. In 'Cabrucas', a selected part of the native trees is preserved, while the understory is substituted by cacao trees. Despite large areas of deforestation, southern Bahia still preserves highly complex forest-like coverage, due to remaining native trees in the cacao plantations (SAMBUICHI and HARIDASAN, 2007). Furthermore, more studies analyzing the ecological significance of 'Cabrucas' are needed to determine the dependence of this system on the native forest remainders and their functionality as ecological corridors linking the same (FARIA et al., 2007).

The 'Reserva Particular do Patrimônio Natural Serra do Teimoso' (RST) is a small hillside forest fragment located in the transition area between wet and mesophytic forests, ranging from 200 to $850 \mathrm{~m}$ above sea level. The edafic and climatic components of the altitude gradient influence the RST floristic composition (AMORIM et al., 2005; THOMAS et al., 2009). At the base of the forest (below $500 \mathrm{~m}$ ), seasonal semideciduous forest species prevail, including Averrhoidium gardnerianum Baill. (Sapindaceae), Cavanillesia arborea (Willd.) K. Shum. (Malvaceae), Caesalpinia echinata Lam. (Fabaceae) and Chrysophyllum subspinosum Monach. (Sapotaceae), among others (AMORIM et al., 2005; THOMAS et al. 2009). At the top (above $500 \mathrm{~m}$ ), wet evergreen forest species are predominant, including Bathysa cuspidata (A. St.-Hil.) Hook. F. (Rubiaceae), Euterpe edulis Mart. (Arecaceae) and Prunus sellowii Hoehne (Rosaceae) (AMORIM et al., 2005; THOMAS et al., 2009).

Microclimate of forest understory presents a great importance for the regeneration and distribution of understory species, for the maintenance of belowground processes and for the ecosystem dynamics overall, being highly dependent in a time and space to the forest structure and weather conditions (CHEN et al., 1999; LÜTTGE, 2008). Even though efforts have been made to improve the knowledge on community diversity in forest areas of southern Bahian forest areas (AMORIM et al., 2005, 2009; FARIA et al., 2007; MARTINI et al., 2007; SAMBUICHI and HARIDASAN, 2007; THOMAS et al., 2008, 2009), at this moment, no studies have analyzed the effects of the forest cover vegetation on understory microclimate.

Aiming to contribute for the knowledge of physical factors affecting community structure and the forest conservation in Southern Bahia, we analyzed the effects of regional climatic seasonality in the understory microclimate (air temperature, relative humidity and vapor pressure deficit) of a fragment of the southern Bahian Atlantic Forest and a rustic cacao agroforestry system.

\section{MATERIAL AND METHODS}

The study was conducted in the 'Fazenda Teimoso' (FT), municipally of Jussari $\left(15^{\circ} 12^{\prime} \mathrm{S}\right.$, $39^{\circ} 29^{\prime} \mathrm{W}$ ), Bahia state, Brazil. The FT covers 520 ha divided in native forest, cocoa cultivation in Cabrucas and livestock pastures. The climate is Am of the Köppen classification with an annual mean precipitation of $1,323 \mathrm{~mm}$ and a mean air relative humidity of $84 \%$. Annual mean air temperature varies between 23 and $24{ }^{\circ} \mathrm{C}$ (BAHIA 2001). The study was conducted in four sites located at the base $\left(\mathrm{RST}_{\mathrm{B}}, 340 \mathrm{~m}\right)$ and the top $\left(\mathrm{RST}_{\mathrm{T}}, 640 \mathrm{~m}\right)$ of the $\mathrm{RST}$, in a 'Cabruca' (CB, $250 \mathrm{~m}$ ) located near the RST and in an open area (OA, $270 \mathrm{~m})$. The $\mathrm{CB}$ has approximately 50 years-old and an area of about 30 ha.

The canopy openness $(C O)$ was analyzed based on 18 sample points through hemispherical photographs; six sample points were marked in each of the three forest covered sites RST $_{B}, \mathrm{RST}_{T}$ and $\mathrm{CB}$ ). In RST the sample points were positioned in the three highest $\left(\mathrm{RST}_{\mathrm{T}}\right)$ and in the three lowest $\left(\mathrm{RST}_{\mathrm{B}}\right)$ parcels of the transect previously marked by Thomas et al. (2009). The parcels with $20 \times 10 \mathrm{~m}$ were divided in sub-parcels with $10 \times 10 \mathrm{~m}$ and the photographs were taken at the central point of each sub-parcel. In CB the sample points were marked considering a minimum distance of $20 \mathrm{~m}$ from the edge and $20 \mathrm{~m}$ among them. A Nikon Coolpix 
4300 digital camera equipped with a hemispherical lens fish-eye $\left(180^{\circ}\right)$ was used. This was mounted on a $1.5 \mathrm{~m}$ tripod, which was leveled using a bubble level. Hemispherical photographs were taken in the RST, during five periods (April, July and October, 2005 and January and April, 2006) and in the CB during three periods (October, 2005 and January and April, 2006). The photographs were analyzed using the GLA software (Gap Light Analyzer - FRAZER et al., 1999). The $C O$ values were transformed arcsine transformed before analysis and the results were subjected to an analysis of variance followed by a Tukey test with $5 \%$ probability.

Air temperature $(\mathrm{Ta})$ and relative humidity $(R H)$ Hobo H8 Pro Series (Onset, USA) sensors were installed at the four sites. The sensors were installed on $1.5 \mathrm{~m}$ wooden stakes. In RST the sensors were installed at the center of the lowest $\left(\mathrm{RST}_{\mathrm{B}}\right)$ and the highest $\left(\mathrm{RST}_{\mathrm{T}}\right)$ parcels of the transect previously marked by Thomas et al. (2009), The Hobo sensors were programmed to produce readings at 30 -minute intervals, for comparisons between the sites. Data were collected between April, 2005 and April, 2006. Due to the difficulty to access the top of RST, the data in $\mathrm{RST}_{\mathrm{T}}$ was collected in intervals of three months between the field campaigns. A problem in the $\mathrm{RST}_{\mathrm{T}}$ 's sensor, probably due to the high $R H$ values, caused the loss of data between the months of November 2005 and January 2006. The daily maximum, minimum and average values were obtained through the $T a$ and $R H$ data. Day and night values were also separated. Readings taken between 06:00 and 17:30, were considered as day values and between 18:00 and 05:30 as night values. Monthly-average and ten-day minimum, day average, maximum and daily and nocturnal $T a$ values $\left(T a_{\text {min }}, T a_{a v r}, T a_{\max }, T a_{d}\right.$ and $T a_{n}$, respectively) and the corresponding $R H$ values $\left(R H_{\min }, R H_{a v r}\right.$, $R H_{\max }, R H_{d}$ and $R H_{n}$, respectively) were calculated. Based on data of $T a$ and $R H$ the vapor pressure deficit $(V P D)$ was calculated, using the formula proposed by Landsberg (1986). Rainfall data were obtained using a pluviometer (Meteoro Instrumentos, Brazil) installed in the OA. Relationships between rainfall and $V P D$ were analyzed using non-linear models.

\section{RESULTS}

The rainfall between April, 2005 and April, 2006 was $1,163 \mathrm{~mm}$. In this period, the months of May, November and December, 2005 and January, March and April, 2006 showed values above
$100 \mathrm{~mm}$ (Figure 1). April, 2006 was the month with the highest rainfall $(170 \mathrm{~mm})$. The months between June and October, 2005 had the lowest rainfall values and October was the driest month $(13.9 \mathrm{~mm})$.

The $\mathrm{CO}$ values varied between $2.5 \%$ in $\mathrm{CB}$ (April, 2006) and $7.7 \%$ in $\mathrm{RST}_{\mathrm{B}}$ and $\mathrm{RST}_{\mathrm{T}}$ (October, 2005) (Table 1). The highest values were observed in October, 2005. These were between 5.9 and $6.5 \%$ in $\mathrm{RST}_{\mathrm{B}}$, between 5.2 and $7.7 \%$ in $\mathrm{RST}_{\mathrm{T}}$ and between 4.0 and $6.1 \%$ in CB. The lowest mean values of $\mathrm{CO}$ were observed in April, 2006. In April, July and October, 2005, the mean CO values were very similar to RST, with non-significant differences $(p>0.05)$ between $\mathrm{RST}_{\mathrm{T}}$ and $\mathrm{RST}_{\mathrm{B}}$.

The mean values of air temperature in $\mathrm{CB}, \mathrm{OA}, \mathrm{RST}_{\mathrm{B}}$ and $\mathrm{RST}_{\mathrm{T}}$ were respectively 22.2 , $22.9,22.1$ and $19.8^{\circ} \mathrm{C}$. The monthly-average values of $\mathrm{Ta}_{\min }$ in $\mathrm{RST}_{\mathrm{B}}$ (Figure 2A) were always higher than the other sites. The lowest $\mathrm{Ta}_{\text {min }}$ values were observed in July, 2005 at all sites; in which CB, $\mathrm{RST}_{\mathrm{T}}$ and $\mathrm{OA}$ had very similar values $\left(16.2^{\circ} \mathrm{C}\right.$ in $\mathrm{CB}, 16.4{ }^{\circ} \mathrm{C}$ in $\mathrm{RST}_{\mathrm{T}}$ and $16.5^{\circ} \mathrm{C}$ in $\left.\mathrm{OA}\right)$. The largest temperature differences among sites were observed for $\mathrm{Ta}_{\text {max }}$ (Figure 2B). Those values were lesser in RST than in CB and OA. The lowest and highest $\mathrm{Ta}_{\text {avr }}$ values were registered in July, 2006 and February, 2006, respectively (Figure 2C). Those values were very similar in the $\mathrm{CB}, \mathrm{OA}$ and $\mathrm{RST}_{\mathrm{B}}$, but always inferior in $\mathrm{RST}_{\mathrm{T}}$. The lowest $\mathrm{Ta}_{\mathrm{d}}$ and $\mathrm{Ta}_{\mathrm{n}}$ values were always registered for $\mathrm{RST}_{\mathrm{T}}$ (Figure $2 \mathrm{D}$ and $2 \mathrm{E}$ ).

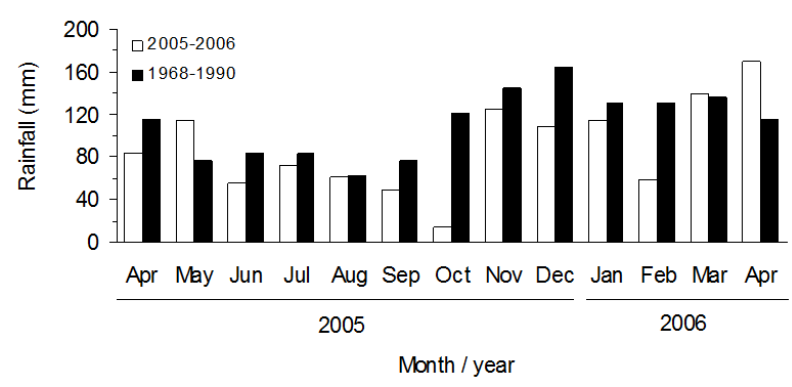

FIGURE 1: Monthly rainfall at 'Fazenda Teimoso', Jussari, Bahia state, Brazil, during the period of study (April 2005 to April 2006) and mean monthly values between 1968 and 1990 (Bahia, 2001).

FIGURA 1: Precipitação pluvial mensal na Fazenda Teimoso, Jussari, Bahia state, Brasil, durante o período do estudo (abril de 2005 a abril de 2006), e valores médios mensais entre 1968 e 1990 (Bahia, 2001). 
TABLE 1: Canopy openness $(C O, \%)$ at the three sites of the 'Fazenda Teimoso', Jussari, Bahia, Brazil, between April, 2005 and April, 2006. Mean values of $C O \pm$ standard errors. Values between parenthesis correspond to the minimum and maximum observed. $(n=6)$

TABELA 1: Abertura do dossel $(C O, \%)$ em três locais da Fazenda Teimoso, Jussari, Bahia, Brasil, entre abril de 2005 e abril de 2006. Valores médios de $C O \pm$ erros padrão. Os valores entre parênteses correspondem aos mínimos e máximos observados.

\begin{tabular}{llllll}
\hline Site & April 2005 & July 2005 & October 2005 & January 2006 & April 2006 \\
\hline RST $_{\mathrm{B}}$ & $4.7 \pm 0.3^{\mathrm{a}}(3.8-5.5)$ & $4.5 \pm 0.2^{\mathrm{a}}(4.0-5.1)$ & $6.1 \pm 0.1^{\mathrm{a}}(5.9-6.5)$ & $3.8 \pm 0.2^{\mathrm{b}}(3.2-4.5)$ & $3.4 \pm 0.1^{\mathrm{b}}(3.1-4.0)$ \\
RST $_{\mathrm{T}}$ & $5.0 \pm 0.4^{\mathrm{a}}(4.1-6.8)$ & $5.4 \pm 0.3^{\mathrm{a}}(4.5-6.2)$ & $6.6 \pm 0.4^{\mathrm{a}}(5.2-7.7)$ & $5.1 \pm 0.3^{\mathrm{a}}(3.7-6.0)$ & $4.7 \pm 0.3^{\mathrm{a}}(3.4-5.1)$ \\
$\mathrm{CB}$ & - & - & $4.8 \pm 0.3^{\mathrm{b}}(4.0-6.1)$ & $4.7 \pm 0.3^{\mathrm{ab}}(3.9-5.2)$ & $3.4 \pm 0.3^{\mathrm{b}}(2.5-4.3)$ \\
\hline
\end{tabular}

Means followed by the same letters do not differ by the Tukey's test at $5 \%$ probability.

The largest differences among sites for the vapor pressure deficit were observed for $V P D_{\text {max }}$ (Figure 2G). The highest monthly-average values of $V P D_{\text {max }}$ were registered in October, $2005(1.8 \mathrm{kPa}$ in $\mathrm{OA}, 1.7 \mathrm{kPa}$ in $\mathrm{CB}, 1.3 \mathrm{kPa}$ in $\mathrm{RST}_{\mathrm{B}}$ and $0.6 \mathrm{kPa}$ in $\mathrm{RST}_{\mathrm{T}}$ ). As expected, the values of $V P D_{\text {min }}$ were lower than $0.1 \mathrm{kPa}$ for all sites and very similar to the values registered at night $\left(V P D_{n}\right)$ (Figure $2 \mathrm{~F}$ and $2 \mathrm{~J})$. The highest monthly-average values of $V P D_{a v r}$ and $V P D_{d}$ were observed in October, 2005 for all sites (Figures $3 \mathrm{H}$ and I). The lowest values of vapor pressure deficit were always observed for $\mathrm{RST}_{\mathrm{T}}$, with exception to the month of April, 2006; in which the lowest values of $V P D_{a v r}$ and $V P D_{d}$ were observed in OA (Figure 2H and 2I). In all sites the ten-day values of $V P D_{\max }$ showed a tendency to decrease with increasing rainfall (Figure 3 ).

Scatterplots comparing ten-day values of $T a_{\text {max }}, T a_{\text {min }}, T_{d}$ and $T_{n}$ measured in OA and in the other sites show direct relationships among temperatures measured in the open area and inside $\mathrm{CB}$ and RST (Figure 4). Nevertheless, there was a tendency of data collected in OA to be closest to the data collected in CB than the data collected in RST. All $T a_{\max }$ (Figure 4A) and $T a_{d}$ (Figure 4C) values were higher in $\mathrm{OA}$ than in the other sites, but $T a_{\text {min }}$ (Figure 4B) and $T a_{n}$ (Figure 4D) were higher in $\mathrm{RST}_{\mathrm{B}}$ than in the other sites. For the all temperature variables, the lowest values were measured in $\mathrm{RST}_{\mathrm{T}}$. The data presented in Figure 4 is consistent with monthly-average data presented in Figure 2, but show more accurately the differences among variable temperatures at different sites.

The lowest and the highest instantaneous values of $T a$ were observed on July 7, 2005 and March 5, 2006, respectively (Figure 5A and 5C). The lowest $T a$ value was $11.8^{\circ} \mathrm{C}$ on July 7, 2005 at 6:30 AM in CB (Figure 5A). Between 10:00 AM and 17:00 PM, the highest $T a$ values were observed in $\mathrm{OA}$ and the lowest ones in $\mathrm{RST}_{\mathrm{T}}$. On the same day, the highest value of $R H$ was registered in $\mathrm{RST}_{\mathrm{T}}$ around midday (Figure 5B). On the other hand, the highest $\mathrm{Ta}$ value $\left(34.4^{\circ} \mathrm{C}\right.$ at $\left.13: 30\right)$ was registered in OA on 05 March, 2006 (Figure 5C). On that same day, the lowest and highest $R H$ values $(44.1 \%)$ were registered in the OA and in the $\mathrm{RST}_{\mathrm{T}}(41.1 \%$ and $65.7 \%$, respectively) (Figure 5D). The maximum instantaneous values of $V P D$ were observed in OA and $\mathrm{CB}$, respectively (Figures $4 \mathrm{C}$ and $5 \mathrm{~F}$ ). Those values were around $1.5 \mathrm{kPa}$ in July 7, 2005 and $2.8 \mathrm{kPa}$ in March, 5 2006. In $\mathrm{RST}_{\mathrm{T}}, V P D$ was below $0.5 \mathrm{kPa}$ in July 7, 2005 and $1.5 \mathrm{kPa}$ in March, 52006.

\section{DISCUSSION}

The sum of rainfall from April, 2005 to March, 2006 (1,163 mm) was inferior to the values previously described for the Jussari region $(1,323 \mathrm{~mm})$. Most of the monthly data obtained, excluding the months of May, 2005, March and April 2006, were below those previously described for the region (BAHIA, 2001). Thus, the period of data collection was marked by two unexpected dry months (October, 2005 and February, 2006), being particularly interesting to analyze the effects of the changes in rainfall pattern along the year and its influence on the understory microclimate.

The values of $C O$ in the forest area (RST) are in accordance with those observed by Trichon et al. (1998) in a humid tropical forest in Sumatra, Indonesia. The results of this study also resemble those obtained by Silva Júnior et al. (2004) in a semi-deciduous forest in southeast Brazil; which varied between 1 and $7 \%$. In contrast, Martins and Rodrigues (2002) obtained values of $C O$ superior to those observed in this study, during the analysis of a gap regeneration phase in a semi-deciduous forest in southeastern Brazil. Considering that high $\mathrm{CO}$ values are indicative of large forest gaps (TRICHON et al., 1998), the RST plots in our study present low 

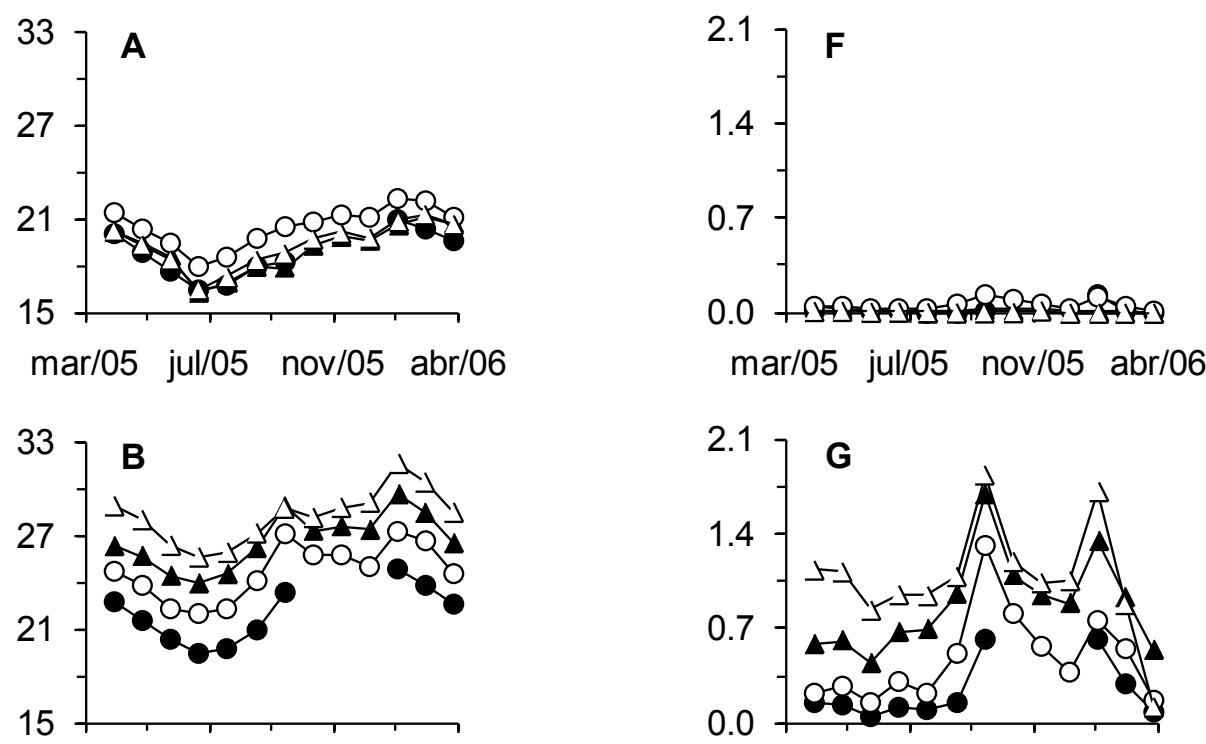

mar/05 jul/05 nov/05 abr/06 mar/05 jul/05 nov/05 abr/06
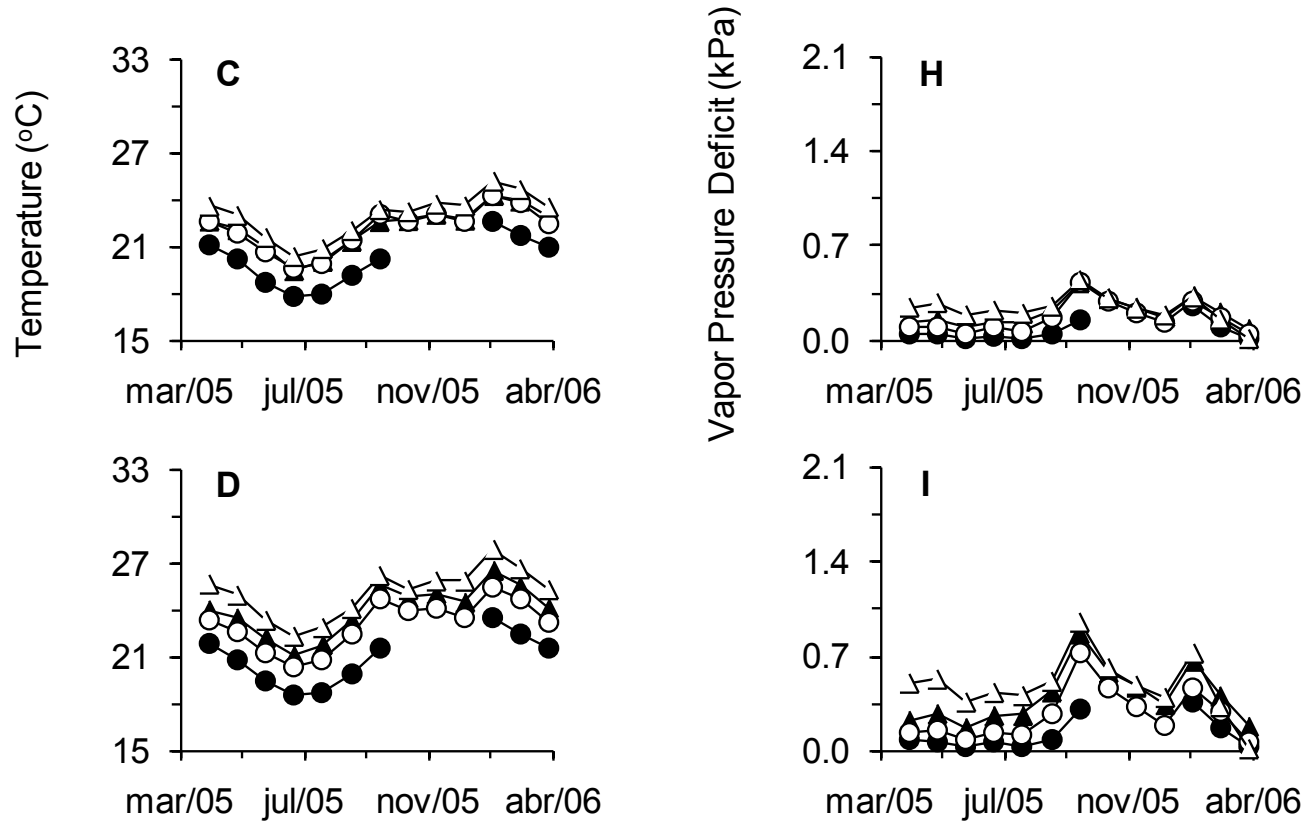

mar/05 jul/05 nov/05 abr/06
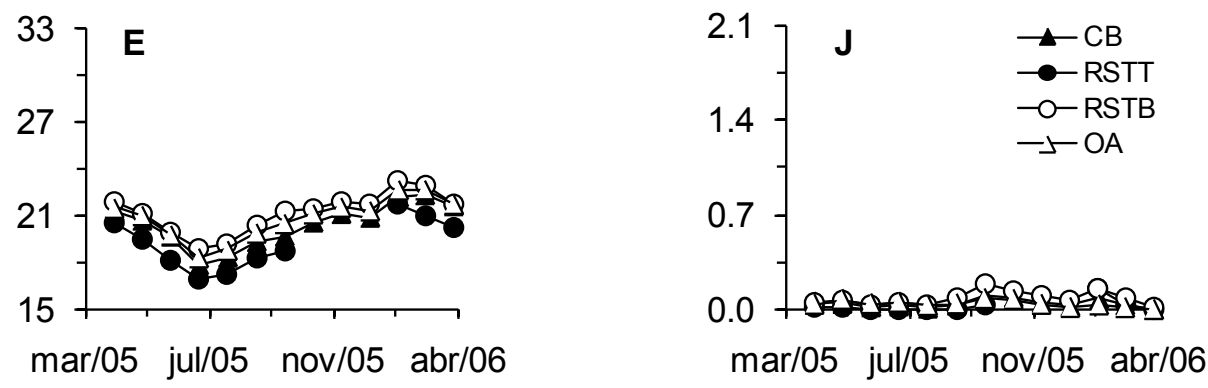

Month

Month

FIGURE 2: Values of $T a_{\text {min }}(\mathrm{A}), T a_{\max }(\mathrm{B}), T a_{a v r}(\mathrm{C}), T a_{d}(\mathrm{D}), T a_{n}(\mathrm{E}), V P D_{\min }(\mathrm{F}), V P D_{\text {max }}(\mathrm{G}), V P D_{a v r}(\mathrm{H})$, $V P D_{d}(\mathrm{I})$ and $V P D_{n}(\mathrm{~J})$ at four sites in the 'Fazenda Teimoso', Jussari, Bahia, Brazil, between April, 2005 and April, 2006.

FIGURA 2: Valores de $T a_{\text {min }}(\mathrm{A}), T a_{\max }(\mathrm{B}), T a_{a v r}(\mathrm{C}), T a_{d}(\mathrm{D}), T a_{n}(\mathrm{E}), V P D_{\min }(\mathrm{F}), V P D_{\max }(\mathrm{G}), V P D_{a v r}(\mathrm{H})$, $V P D_{d}(\mathrm{I})$ e $V P D_{n}(\mathrm{~J})$ em quatro locais na Fazenda Teimoso, Jussari, Bahia, Brasil, entre abril de 2005 e abril de 2006. 


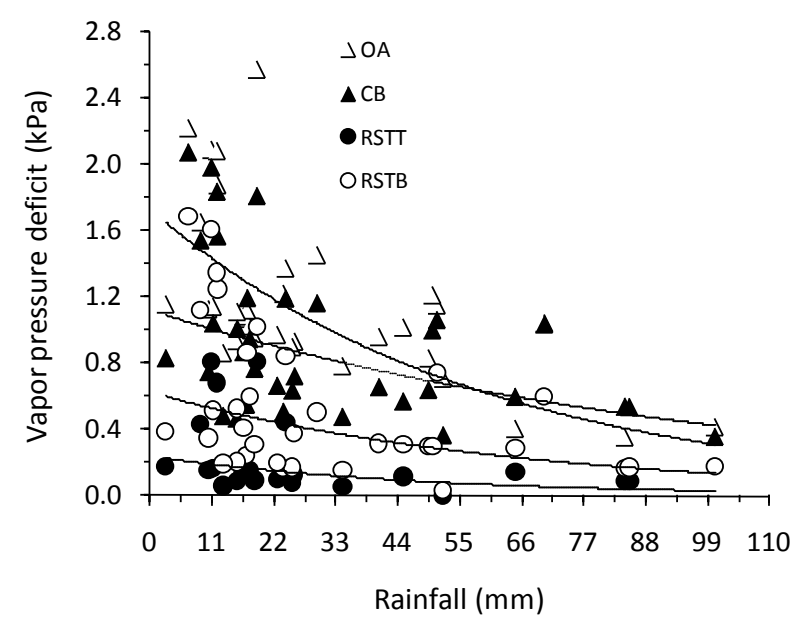

FIGURE 3: Relationships between rainfall and $V P D_{\max }$ in three forested sites at 'Fazenda Teimoso', Jussari, Bahia state, Brazil.

FIGURA 3: Relações entre a precipitação pluvial e $V P D_{\max }$ em em quatro locais na Fazenda Teimoso, Jussari, Bahia, Brasil.

$C O$ values in comparison to data obtained by other authors (TRICHON et al., 1998; MARTINS and RODRIGUES, 2002; NASCIMENTO et al., 2007). The canopy openness values below $8 \%$ (Table 1 ) are indicatives that $\mathrm{RST}_{\mathrm{T}}$ and $\mathrm{RST}_{\mathrm{B}}$ present a relatively closed canopy.

The low values of $C O$ observed in the Cabruca (CB) can be explained by the fact that the hemispherical photographs were taken just below the canopy layer of the cocoa trees (i.e. $1.5 \mathrm{~m}$ above ground). In general, light intensity under the shade of cacao trees is very low because of the canopy architecture and the size of the leaves. For example, Miyaji et al. (1997) reported that the relative light intensity in the lower canopy layer of shaded cacao trees (60-90 $\mathrm{cm}$ above ground) varied from 4 to $10 \%$ of the full sunlight. Similar results were also found by Lima (2007), which reported that the relative light intensity below the canopy of cacao trees was around $5 \%$ of the full sunlight. The lowest values of $C O$ found in the RST ${ }_{\mathrm{B}}$ in January 2006 and April 2006 are related to the semideciduous characteristic of the most frequent tree species in this part of the forest (THOMAS et al., 2009) and to the low rainfall values in the months of October 2005 and February 2006, respectively.

The highest values of $T a_{a v r}$ and $T a_{\max }$ observed in $\mathrm{OA}$ in comparison with values measured in the forested sites are in agreement with information found in the literature (HERNANDES et al., 2002;
PEZZOPANE et al., 2002; PEZZOPANE et al., 2005). Among all temperature variables, the largest differences were verified for $\mathrm{Ta}_{\max }$; in which the greatest difference was observed between $\mathrm{RST}_{\mathrm{T}}$ and OA. Within the forest sites (RST), the highest $T a$ values were found in the lowest portion $\left(\mathrm{RST}_{\mathrm{B}}\right)$. During the period of data collection, the $T a_{\min }$ was greatest in the $\mathrm{RST}_{\mathrm{B}}$. Hernandes et al. (2002), for example, also observed an inferior minimum temperature in a forest fragment in relation to the vineyard and weather station (external environments) during the coldest period of the year. According to the authors, this may be due to the semi-deciduous characteristic of the study site. On the other hand, the greatest $T a_{d}$ and $T a_{n}$ values were in the OA and in the $\mathrm{RST}_{\mathrm{B}}$.

Among all forest sites the lowest values of $V P D$ were generally observed in the $\mathrm{RST}_{\mathrm{T}}$, demonstrating the expressive effect of the altitude gradient and forest environments on air humidity (LÜTTGE, 2008). In contrast, incongruent data was collected in April, 2006, in which the lowest $V P D_{d}$ and $V P D_{\min }$ values were registered in the OA (Figure 2). This apparent incongruence can be explained by the fact that April, 2006 was characterized by the highest rainfall in the whole period of data collection (Figure 1). Our results demonstrate that $V P D$ is dependent on the seasonal rainfall fluctuations. For instance, October, 2005 was characterized by the lowest amount of precipitation and the highest $V P D$ values and April, 2006 had the highest rainfall precipitation and the lowest $V P D$ values. The high $V P D$ values in February, 2006 were probably related to the highest $T a$ values as well the low precipitation.

The data collected during this study was sufficient to demonstrate that the understory microenvironment in $\mathrm{CB}$ is more similar to that observed in OA than in the forest sites (RST). Alternatively, we also should consider that the altitude gradient could be affecting those differences, because the quota for the sensors located in OA, $\mathrm{CB}, \mathrm{RST}_{\mathrm{B}}$ and $\mathrm{RST}_{\mathrm{T}}$ were respectively 270,250 , 340 and $670 \mathrm{~m}$. In a study aiming to analyze the effects of dry and wet seasons on the microclimate of a cacao plantation in Ilhéus, Bahia state, Brazil, Miranda et al. (1994) also found that temperature and humidity were quite similar to an open area. In spite of the great heterogeneity of 'Cabrucas' of southern Bahia, our results were in agreement with those reported by Miranda et al. (1994), showing that the values of $T a$ and $V P D$ in $C B$ during the measurement period were closest to the values 
measured in OA than inside the forest.

The growth of plants, the accumulation and partition of photo-assimilates and the production of secondary compounds are factors that affect seedling establishment and forest regeneration (KITAJIMA, 1994). Accordingly, the understory light environment strongly affects forest regeneration because the light is the primary source of energy to photosynthesis (HOGAN and MACHADO, 2002). On the other hand, environmental factors as temperature and humidity are also important. Temperature affects the carbon balance (i.e. root and shoot respiration) and overall plant metabolism. Air humidity directly affects water flux in plants, cell turgor, stomatal conductance and, consequently, photosynthesis (SCHULZE et al., 2002). In our study $C O$ values were below $8 \%$ through the year and were very similar among RST environments.
Despite differences in canopy structure, probably affecting the quality of radiation which reaches the understory, the light availability in the understory seems not to be the main factor that affects the regeneration of different species along the altitude gradient.

Vapor pressure deficit is a very important environmental factor because is directly related to stomatal conductance and leaf gas exchange (LANDSBERG, 1986; FRANKS and FARQUHAR, 1999). Even though some recent results have shown that $V P D$ does not have a significant long-term effect on growth of tropical evergreen rainforest trees (CUNNINGHAM, 2006) it is clear that there is an association between the distribution of species along the altitude gradient in RST and relative humidity. In addition, there are numerous references showing that the sensitivity to $V P D$ is
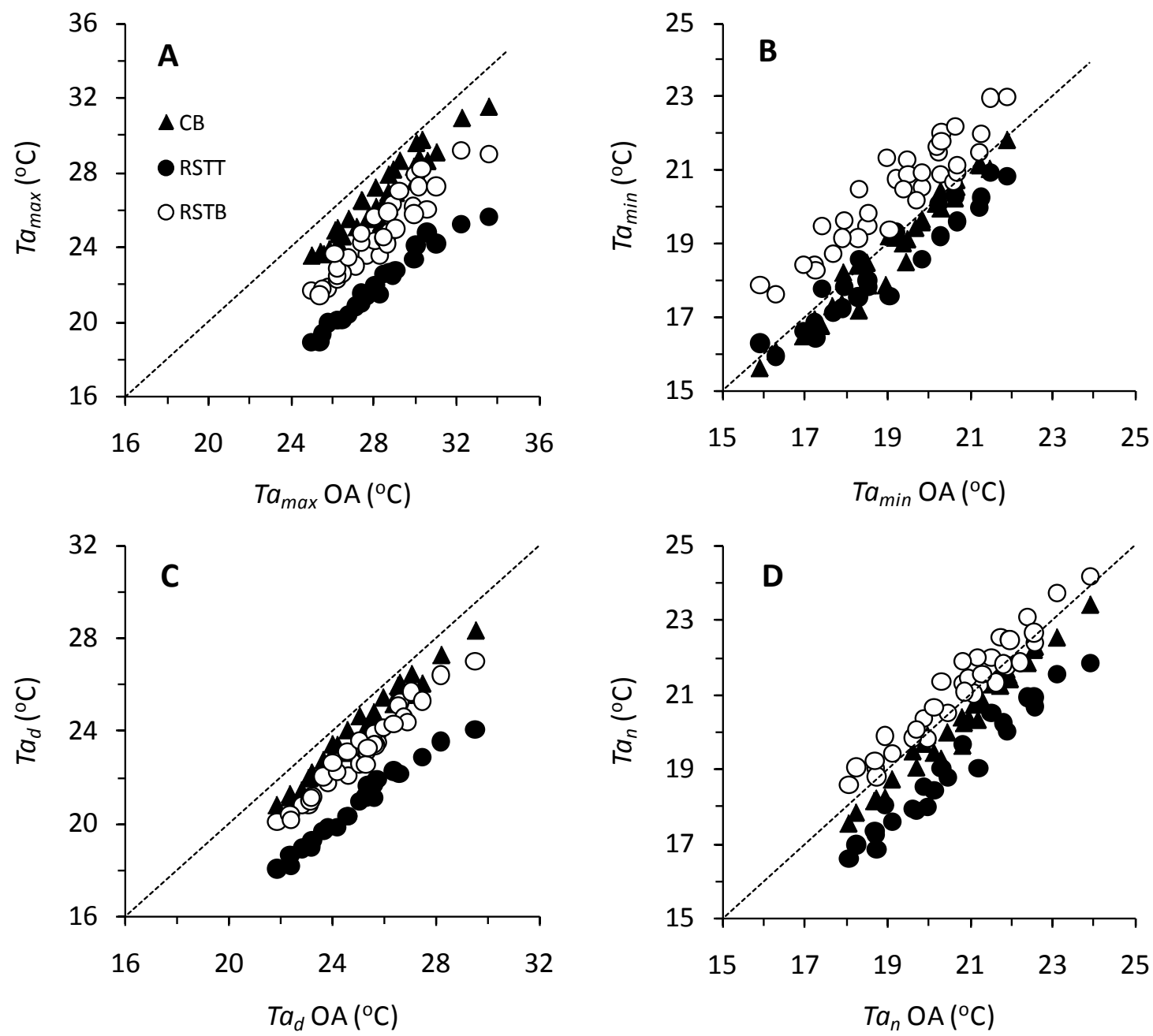

FIGURE 4: Scatterplot of air temperature in the open area (OA) and three forest sites in 'Fazenda Teimoso', Jussari, Bahia state, Brazil. The broken lines indicate 1:1.

FIGURA 4: Gráfico de dispersão da temperatura do ar numa área aberta (OA) e em três ambientes florestais na Fazenda Teimoso, Jussari, Bahia, Brasil. Linhas tracejadas indicam 1:1. 

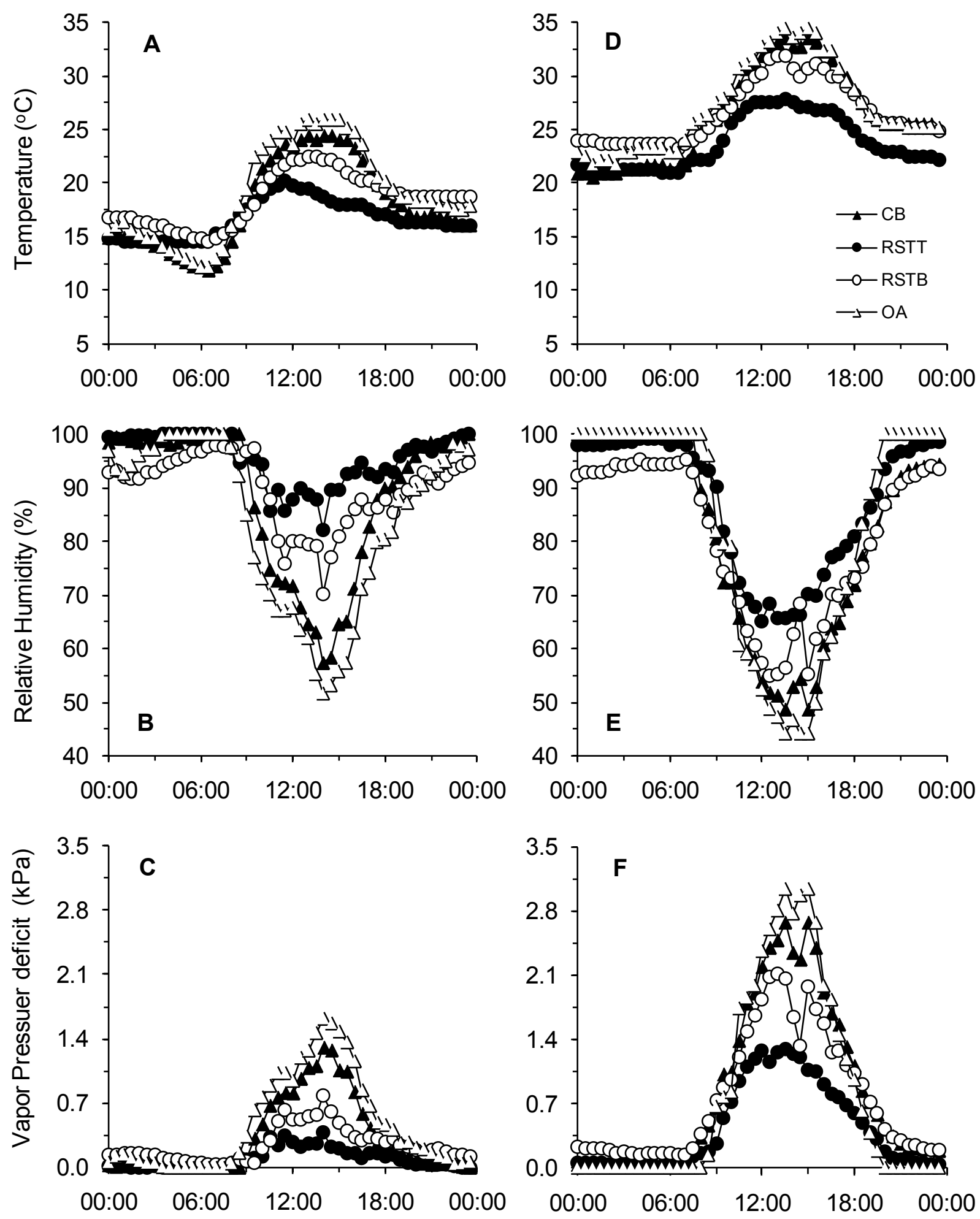

Hour

FIGURE 5: Air temperature, air relative humidity and vapor pressure deficit on two contrasting days, 10 July, 2005 (A, B and C) and 05 March, 2006 (D, E and F), at four sites in 'Fazenda Teimoso', Jussari, Bahia state, Brazil.

FIGURA 5: Temperatura, umidade relativa e déficit de pressão de vapor do ar em dois dias contrastantes, 10 de julho de 2005 (A, B e C) e 5 de março de 2006 (D, E e F), em quatro locais na Fazenda Teimoso, Jussari, Bahia, Brasil. 
widely variable among plant species (FRANKS and FARQUHAR, 1999; CUNNINGHAM, 2004). In this way, studies aiming to investigate the effects of $V P D$ on the growth of species that only occur in $\mathrm{RST}_{\mathrm{T}}$ or $\mathrm{RST}_{\mathrm{B}}$ may provide interesting information on the effects of air humidity in the canopy structure and tropical forest dynamics.

In summary, the largest differences among the sites were observed in the monthly-average values of the maximum air temperature $\left(T a_{\max }\right)$. These values were always lower inside the mature forest (RST) in comparison to the CB and the OA. Changes in the monthly rainfall throughout the year affected $C O$ and $V P D$. Seasonal changes in the climatic variables and the constant low values of $V P D$ through the year in $\mathrm{RST}_{\mathrm{T}}$ are in accordance with the floristic composition along the altitude gradient of the RST. During the period of measurements the values of $T a$ and $V P D$ in $\mathrm{CB}$ were closest to the values measured in $\mathrm{OA}$ than to the values measured inside the forest.

\section{CONCLUSIONS}

The largest differences among the sites were observed in the monthly-average values of the maximum air temperature $\left(\mathrm{Ta}_{\max }\right)$. These values were always lower inside the mature forest (RST) in comparison to the $\mathrm{CB}$ and the OA. Changes in the monthly rainfall throughout the year affected $C O$ and $V P D$. Seasonal changes in the climatic variables and the constant low values of $V P D$ through the year in $\mathrm{RST}_{\mathrm{T}}$ are in accordance with the floristic composition along the altitude gradient of the RST. During the period of measurements the values of $\underline{T a}$ and $V P D$ in $\mathrm{CB}$ were closest to the values measured in $\mathrm{OA}$ than to the values measured inside the forest.

\section{ACKNOWLEDGMENTS}

We acknowledge the contributions of Francisco and Edvaldo in assisting with field measurements. We are also grateful to Henrique F. Berbert de Carvalho and Lucélia de Melo Berbert, the owners of 'Fazenda Teimoso', for their helpfulness. Furthermore, we acknowledge 'Núcleo de Bacias Hidrográficas' of 'Universidade Estadual de Santa Cruz (UESC)', which provided rainfall data. Financial support for the experiment was provided by UESC, 'Fundação de Amparo à Pesquisa do Estado da Bahia' (FAPESB) and 'Conselho Nacional de Desenvolvimento Científico e Tecnológico' (CNPq). M.P Pinheiro was provided with a scholarship by CAPES. J.A. Oliveira Filho was given a scholarship by CNPq-Brazil. André M. Amorim and Marcelo S. Mielke gratefully acknowledge CNPq-Brazil for the concession of a fellowship of scientific productivity.

\section{REFERENCES}

AMORIM, A. M. et al. Angiospermas em remanescentes de floresta montana no sul da Bahia, Brasil. Biota Neotropica, São Paulo, v. 9, p. 313348, 2009.

AMORIM, A.M. et al. The vascular plants of a forest fragment in southern Bahia, Brazil. SIDA, Dallas, v. 21, p. 1727-1752, Aug. 2005.

BAHIA, GOVERNODOESTADO. Caracterização

Climatológica: Programa de Recuperação das Bacias dos Rios Cachoeira e Almada. Ilhéus: Superintendência de Recursos Hídricos, 2001.

CHEN, J. et al. Microclimate in Forest Ecosystem and Landscape Ecology. BioScience, Washington, v. 49, p. 288-297, Jan. 1999.

CUNNINGHAM, S. Effects of vapour pressure deficit on growth of temperate and tropical evergreen rainforest trees of Australia. Acta Oecologica, Maryland Heights, v. 30, p. 399-406, Nov./Dec. 2006.

CUNNINGHAM, S. Stomatal sensitivity to vapour pressure deficit of temperate and tropical evergreen rainforest trees of Australia. Trees, Berlin, v. 18, p. 399-407, July 2004.

FARIA, D. et al. Ferns, frogs, lizards, birds and bats in forest fragments and shade cacao plantations in two contrasting landscapes in the Atlantic Forest, Brazil. Biodiversity and Conservation, Dordrecht, v. 16, p. 2335-2357,July 2007.

FRANKS, P. J.; FARQUHAR, G. D. A relationship between humidity response, growth form and photosynthetic operating point in $\mathrm{C} 3$ plants. Plant Cell and Environment, Bognor Regis, v. 22, p. 1337-1349, Nov. 1999.

FRAZER, G. W.; CANHAM, C. D.; LERTZMAN, K. P. Gap Light Analyzer (GLA). Millbrook: Simon Fraser University, 1999.

HERNANDES, J. L.; PEDRO JR., M. J.; BARDIN, L. Diferenças estacionais entre variáveis microclimáticas para ambientes de interior de mata, vinhedo e posto meteorológico em Jundiaí (SP). Bragantia, Campinas, v. 61, p. 169-180, maio/ago. 2002.

HOGAN, K. P.; MACHADO, J. L. La luz solar: consecuencias biológicas y medición. In: 
GUARIGUATA, M. R.; KATTAN, G. H. (Eds.) Ecologia y conservación de bosques neotropicales. Cartago: Libro Universitario Regional, 2002. p.119143.

KITAJIMA, K. Relative importance of photosynthetic traits and allocation patterns as correlates of seedling shade tolerance of 13 tropical trees. Oecologia, Berlin, v. 98, p. 419-428, Aug. 1994.

LANDSBERG, J.J. Physiological ecology of forest production. San Diego: Academic Press, 1986. 198p.

LIMA, M. A. O. Crescimento inicial de três especies arbóreas nativas e cultivadas em condições de sombreamento artificial, pleno sol e Cabruca. 2007. 58 f. Dissertação (Mestrado em Produção Vegetal) - Universidade Estadual de Santa Cruz, Ilhéus, 2007.

LÜTTGE, U. Physiological ecology of tropical plants. Berlin: Springer, 2008. 458 p.

MARTINI, A.M.Z. et al. A hot-point within a hotspot: a high diversity site in Brazil's Atlantic Forest.

Biodiversity and Conservation, Dordrecht, v. 16, p. 3111-3128, Oct. 2007.

MARTINS, S. V.; RODRIGUES, R. R. Gap-phase regeneration in a semideciduous mesophytic forest, south-eastern Brazil. Plant Ecology, Dordrecht, v. 163, p. 51-62, Nov. 2002.

MIRANDA, R. A. C. et al. Daily characterization of air temperature and relative humidity profiles in a cocoa plantation. Pesquisa Agropecuária Brasileira, Brasilia, v. 29, p. 345-353, mar. 1994. MIYAJI, K. I.; SILVA, W. S.; ALVIM, P. T. Productivity of leaves of a tropical tree, Theobroma cacao, grown under shading, in relation to leaf age and light conditions within the canopy. New Phytologist, Lancaster, v. 137, p. 463-472, Mar. 1997.

MORI, S.; SILVA, L. A. M. The herbarium of the "Centro de Pesquisas do Cacau" at Itabuna, Brazil. Brittonia, Berlin, v. 31, p. 177-196, Apr. 1979.

MYERS, N. et al. Biodiversity hotspots for conservation priorities. Nature, Londres, v. 403, p. 853-858, Feb. 2000.

NASCIMENTO, A. R. T.; FAGG, J. M. F.; FAGG, C. W. Canopy openness and LAI estimates in two seasonality deciduous forest on limestone outcrops in central Brazil using hemispherical photographs.
Revista Arvore, Viçosa, v. 31, p. 167-176, jan./fev. 2007.

PEZZOPANE, J. E. M. et al. Caracterização da radiação solar em fragmento de Mata Atlântica. Revista Brasileira de Agrometeorologia, Santa Maria, v. 13, p. 11-19, jan./abr. 2005.

PEZZOPANE, J. E. M. et al. Temperatura do solo no interior de um fragmento de floresta secundária semidecidual. Revista Brasileira de Agrometeorologia, Santa Maria, v. 10, p. 1-8, jan./ jun. 2002.

SAMBUICHI, R. H. R.; HARIDASAN, M. Recovery of species richness and conservation of native Atlantic Forest trees in the cacao plantations of southern Bahia in Brazil. Biodiversity and Conservation, Dordrecht, v. 16, p. 3681-3701, Dec. 2007.

SHULZE, E-D., BECK, E.; MULLERHOHENSTEIN, K. Plant Ecology. Berlin: Springer, 2002. $700 \mathrm{p}$.

SILVA JÚNIOR, W.M. et al. Regeneração natural de espécies arbustivo-arbóreas em dois trechos de uma Floresta Estacional Semidecidual, Viçosa, MG. Scientia Forestalis, Piracicaba, v. 66, p. 169179, dez. 2004.

THOMAS, W. W. et al. Diversity of woody plants in the Atlantic coastal forest of southern Bahia, Brazil. Memoirs of the New York Botanical Garden, New York, v. 100, p. 21-66, 2008.

THOMAS, W. W. et al. Composição florística e estrutura do componente arbóreo de uma área transicional de Floresta Atlântica no sul da Bahia, Brasil. Revista Brasileira de Botânica, São Paulo, v. 32, n. 1, p. 65-78, jan./mar. 2009.

THOMAS, W. W. et al. Plant endemism in two forests in Southern Bahia. Biodiversity and Conservation, Dordrecht, v. 7, p. 311-322, Mar. 1998.

THOMAS, W. W.; BARBOSA, M. R. V. Natural vegetation types in the Atlantic Coastal Forest of Northeastern Brazil. Memoirs of the New York Botanical Garden, New York, v. 100, p. 6-20, 2008.

TRICHON, V.; WALTHER, J. N.; LAUMONIER, Y. Identifying spatial patterns in the tropical rain forest structure using hemispherical photographs. Plant Ecology, Dordrecht, v. 137, p. 227-244, Aug. 1998. 